\title{
Building a nation through a dam: the case of Rogun in Tajikistan
}

Article

Accepted Version

Menga, F. (2015) Building a nation through a dam: the case of Rogun in Tajikistan. Nationalities Papers, 43 (3). pp. 479-494. ISSN 0090-5992 doi:

https://doi.org/10.1080/00905992.2014.924489 Available at https://centaur.reading.ac.uk/72320/

It is advisable to refer to the publisher's version if you intend to cite from the work. See Guidance on citing.

Published version at: http://dx.doi.org/10.1080/00905992.2014.924489

To link to this article DOI: http://dx.doi.org/10.1080/00905992.2014.924489

Publisher: Taylor \& Francis

All outputs in CentAUR are protected by Intellectual Property Rights law, including copyright law. Copyright and IPR is retained by the creators or other copyright holders. Terms and conditions for use of this material are defined in the End User Agreement.

\section{www.reading.ac.uk/centaur}

\section{CentAUR}

Central Archive at the University of Reading

Reading's research outputs online 


\title{
Building a nation through a dam: the case of Rogun in Tajikistan \\ Filippo Menga \\ Email: filippomenga@gmail.com
}

This is an Accepted Manuscript of an article published by Taylor \& Francis Group in Nationalities

Papers, Volume 43, Issue 3, pages 479-494, on 08/07/2014, available online:

http://www.tandfonline.com/doi/abs/10.1080/00905992.2014.924489/ [Article DOI

10.1080/00905992.2014.924489].

\begin{abstract}
Ruling elites can use the symbolism of major dams to gain legitimacy and bolster a sense of national identity and patriotism. The Rogun dam in Tajikistan is a gigantic hydraulic infrastructure that if and when finished will be the tallest in the world, allowing the country to gain energy self-sufficiency. Furthermore, by projecting an image of progress and success, such a structure can contribute to creating and strengthening a nationalistic discourse even before its completion.

This paper begins by introducing the concept of nation-building in relation with the Central Asian setting, and then connects it with the literature exploring the interplay between water and power. Subsequently, the focus moves to the Rogun project, illustrating the main traits of the Rogun ideology and outlining the rhetorical legitimation strategies used by the Tajik government to frame the dam as a nationally cohesive and patriotic project.
\end{abstract}

Keywords: nation-building; water; Tajikistan; Rogun; dams. 


\section{Introduction}

Research on water and social power (Wittfogel, 1957; Worster 1985; Reisner 1993; Swyngedouw 1999; Giglioli and Swyngedouw 2008) has highlighted how ruling political elites can increase their influence and preserve social control through the realization of large hydraulic infrastructures. So far, however, there has been little discussion about how a ruling elite can use the symbolic value of a large hydraulic project to construct and disseminate its own idea of the nation and legitimize its hold on power. On this regard, the concept of nations as social or cultural constructs seems to fit well within the post-Soviet context, and scholars working on the post-Soviet space (Kuzio 2002; Kolstø 2006; Polese and Wylegala 2008), and more specifically on Central Asia (Laruelle 2007; Marat 2008; Blakkisrud and Nozimova 2010; Cummings 2010; Roche and Hohmann 2011), have offered specific examples of how languages, discourses and symbols are used by ruling elites to produce meanings, define the nation and create ideologies.

The present article contributes to this body of research by taking as a case study the Rogun Dam in Tajikistan, and illustrating the rhetorical legitimation strategies used by the Tajik government to frame the dam as a nationally cohesive and patriotic project. Conceived during the golden years of the hydraulic mission of the Soviet administration, Rogun is a gigantic dam on the Vakhsh ${ }^{1}$ river that if and when finished, with its 335-meter of height, would be the tallest in the world, giving another record to the country that in 2011 erected the world's tallest flagpole as a symbol of statehood and patriotism (BBC Monitoring 2011b). The symbolic meaning attached to the Rogun dam, it is argued, can possibly be the key to explaining the Government of Tajikistan's (GoT) insistence over the last twenty years to realize a project that, besides being outdated and too costly to be funded by its national resources alone (Schmidt 2007), has caused the deterioration of Tajik relations with its neighbors and, in particular, with Uzbekistan. In an effort aimed at persuading its citizens and the international community that the construction of Rogun is a fundamental achievement for the country, the GoT has created what can be defined a "Rogun ideology".

Indeed, the Central Asian political environment seems particularly suitable for observing how the symbolism of a major dam can be used by a ruling elite to produce a national ideology and legitimize its position. This is evident for at least two reasons. First, as Rogers Brubaker (1996, 29) puts it, no other state has gone so far as the Soviet Union "in sponsoring, codifying, institutionalizing, even (in 
some cases) inventing nationhood and nationality on the sub-state level, while at the same time doing nothing to institutionalize them on the level of the state as a whole." If, on the one hand, such an institutionalized definition of nationhood played a major role in the disintegration of the Soviet state, on the other hand, it has shaped and structured the formation of national identities in successor states (Brubaker 1996). Second, the void left by the collapse of the Soviet Union led to the birth of what Hobsbawn (1992, 10) would have called invented nations, in which "nationalism comes before nations." The key contradiction, according to Olivier Roy (2000), is that the Central Asian states were created during the Soviet period, but their independence came as a result of the end of that period: since Stalin could no longer be the father of the nation, the Central Asian rulers had to re-evaluate or reconstruct their pasts. As Communism could no longer provide a basis for legitimacy to national governments, former Communist leaders took a nationalist turn to enhance the perceived legitimacy of their authority (Mellon 2010).

This article also represents an effort to examine how the construction of a national identity can overlap with the construction of a large dam, to the extent that the dam itself becomes a national image. Major dams ${ }^{2}$ are indeed among the largest structures built by humans and are, perhaps, the most spectacular way to tame water resources. Apart from serving practical purposes (e.g. generating electricity, controlling water flows and allowing for irrigated agriculture), dams are also powerful political symbols that can be used to build and reinforce national identities and legitimize those in power (Mitchell 2002).

Based on these assumptions, the focus of this study is placed on the Tajik political elite and on their discursive constructions of the Rogun dam at the national as well as at the international level. These two dimensions are interconnected, since the dam can be portrayed as a symbol of progress and success, but it can also be directly related to the rivalry between Tajikistan and Uzbekistan and the assertion of Tajik national interests.

The sources used for the case study include official and non-official documents. The former consist of official texts, such as speeches delivered by the President and his ministers at national and international summits, official statements and government documents; the latter comprise news reports produced by state-owned TV channels - television is still the most important source of information for Tajik citizens $^{3}$ - and news agencies, which in Tajikistan are tightly controlled and serve as the mouthpiece of the government (Olcott 2012, 35-38). Non-official sources serve the purpose of this 
analysis particularly well, as governments tend to use news reports to construct knowledge and disseminate a particular truth about social events (Cloke et al. 2004, 62-64).

Specifically, the following sources have been systematically scrutinized: official speeches and documents as they are reported in the official websites of the President (www.president.tj/ru/), Parliament (www.parlament.tj/ru/), and The Strategic Research Center under the President (www.mts.tj/ru/); the transcripts of the flagship news program "Akhbor" broadcasted by Tajik Television First Channel (TTFC) and provided by BBC Monitoring Central Asia Unit; as well as the archives of the Avesta and Khovar news agencies. The period analyzed is from January 2005 (2005 is the year in which construction works restarted at the Rogun site) and until June 2013. The analysis of the documents focuses on identifying how specific identities, practices, meanings and knowledge are created by an actor in describing something in one way or another.

\section{Nation-building and the politics of large dams}

As Benedict Anderson (2006, 3) noted, "[n]ation, nationality, nationalism - all have proved notoriously difficult to define, let alone analyse." Hugh Seton Watson $(1977,5)$ pointed out that "a nation exists when a significant number of people in a community consider themselves to form a nation." Based on its subjective character, the nation is defined as a social or cultural construct with limited spatial and demographic extent, in line with Anderson's (2006) interpretation of the nation as an "imagined political community." Thereby, considering the nation as an immaterial entity does not mean that a nation cannot be constructed or built. Indeed, the concept of nation-building gained prominence in the United States in the 1960s, mostly thanks to the work of Karl Deutsch and William Folz (1963). The term was chiefly used to describe the greater integration of state and society, as citizenship brought loyalty to the modern nation-states (Dobbins 2003). Still, the concept has been highly debated, and Polese (2011) observed that there are at least four distinct and incompatible interpretations of the term nation-building that make it difficult to come up with an uncontested definition of the concept. Partially drawing on the definition provided by Kolst $\varnothing$ and Blakkisrud (2004, vii), for the purpose of this paper the term nation-building is defined as the set of policies aimed at creating a common national identity and a sense of patriotism and loyalty towards the state.

Symbols and symbolism can play a crucial role in the nation-building process, and ruling elites often use them to motivate and mobilize their population (Smith 1998). In this regard, the research is formed 
by some basic assumptions underlying Pierre Bourdieu's theories on symbolic power. As Bourdieu (Bourdieu and Thompson 1991, 170) defines it, symbolic power is the power of "constituting the given through utterances, of making people see and believe [...] an almost magical power which enables one to obtain the equivalent of what is obtained through force (whether physical or economic), by virtue of the specific effects of mobilization." Symbolic power is effective when complemented by misrecognition (méconnaissance) or, in other words, if the messages conveyed through words and slogans are considered legitimate by those who receive them (Bourdieu and Passeron 1977, 5). Recognizing the importance of symbolic power helps understanding how reality can be constructed using symbols and, in the specific case of the Rogun dam, how the realization of a mega dam can be used by a political elite to create an ideology that helps legitimize its actions, boost its popularity, and maintain power.

Indeed dams, and their ability to dominate nature by using its power to serve the needs of society, can have a strong symbolic value. Between the end of the nineteenth century and the 1970s, the socalled "hydraulic mission" to control nature and conquer the desert was launched worldwide, and some of the largest and most iconic dam projects were realized around the world, becoming highly symbolic both within the nation and outside (Frey 1993). Examples are the Marathon dam, hailed as the greatest achievement of Greece after the Parthenon (Kaika 2006, 297), and the massive Hoover Dam in Nevada, which led US Secretary of the Interior Harold Ickes to declare upon completion: "pridefully, man acclaims his conquest of nature" (McCool 2012, 23). Similarly, in 1954, at the inauguration of the high Bhakra dam, Prime Minister Jawahar Lal Nehru audaciously described dams as the "temples of modern India"4 (Sharma 1989). In Nasser's Egypt, the gigantic Aswan High Dam, completed in 1971 with Soviet support, became "the centrepiece of postwar nation making" in a country in which "large dams offered a way to build not just irrigation and power systems, but nation-states in themselves" (Mitchell 2002, 44-45). John Waterbury (1979, 108) observed that as relations between Egypt and Britain deteriorated in the 1950s, "Nasser and his associates could no longer regard the dam as simply a big engineering project, but rather came to hold it up as the symbol of Egypt's will to resist imperialist endeavors to destroy the revolution." If, on the one side, those who supported the Aswan High Dam were treated as patriots, on the other side, those who criticized it were "thought of as subversive or even treasonous" (Waterbury 1979, 117). Indian activist Arundhati Roy identified a similar correlation between patriotism and dams on her analysis of the Sardar Sarovar Dam project in India (Roy and Aradhana 2002), and McCully $(2001,264)$ noted that critics of the planned Castanho Dam in Brazil 
were accused by the local governor Tasso Jereissati of using "wicked insinuations and unfounded and unpatriotic criticisms."

Building dams can thus have a relevance to the nation-building process, also considering that Pal Kolstø $(2000$, 16) suggested that nation-building can be seen as an architectural metaphor which "implies the existence of consciously acting agents such as architects, engineers, carpenters, and the like." And as it was mentioned, this is also relevant to the Central Asian political setting, in which states created a legitimation framework through the invention of national symbols, in the form of "landslide electoral victories, Independence Day parades with displays of military might, historical writings, leaders' addresses to the nation, national holidays, flags and anthems, the currency, the capital and major national monuments" (Matveeva 2009, 1101). The main concern of Central Asian authoritarian rulers is to maintain power (Cummings 2002), and a key way to do so without employing military force is to use symbols, since symbolism appears to have a crucial role in regional politics (Cummings 2010). Also, as Murzakulova and Schoeberlein (2009) have illustrated, Central Asian political elites - particularly the presidents - placed great emphasis on the production of national ideologies that could provide them with legitimacy, and Central Asian states have been quite successful in retaining a monopoly over the production of symbols.

As a result, through the construction of a dam ideology, the Tajik political elite can gain legitimacy while diverting attention from more pressing matters and promising a better future to its population. Furthermore, the Rogun dam and the Uzbek opposition to its construction can be used to strengthen a specific nationalistic propaganda. If a large dam symbolizes the nation, those who question it become the enemies of the nation. Therefore, the construction of a dam against the will of a neighboring country can be portrayed as a symbol of internal cohesion that incarnates the nation's right to selfdetermination.

\section{Tajikistan and the Rogun dam}

The Rogun dam was originally conceived by the Soviet Union in the 1960s as a dual-purpose structure for irrigation water management and for hydroelectricity. The project consists of a 335-meter high structure, a reservoir with a volume of $13.3 \mathrm{~km}^{3}$ and six 600 megawatt (MW) turbines, resulting in a total installed capacity of 3,600 MW (Schmidt, 2007). Compared with other dams, Rogun would be the tallest in the world - the fourth being Nurek (300-meter) - and the twentieth for installed capacity 
(ICOLD, n.d.). Although intense construction started in 1982 (United Nations Environment Programme 2011, 48), due to the collapse of the Soviet Union and the worsening political situation in Tajikistan, work on the Rogun site was stopped in 1991. Furthermore, in 1993 - which was originally the year set for its first unit to start producing electricity (Yerofeyeva 2002) - the upper coffer-dam was washed away by a powerful flash-flood. Combined with inadequate management caused by the civil war, the flood destroyed most of the existing structure (Fradchuk 2010), frustrating two decades of efforts and an investment of US\$ 800 million. Nevertheless, the idea of building Rogun was already too well established in the minds of Tajik bureaucrats to be washed away with the flood. In 2005, following a deal with the Russian aluminum giant RusAl (Interfax, 2004), construction works at the dam site restarted and continued until 2012, when they were suspended by the Tajik government which is awaiting the release, review and discussion of a feasibility study being executed by the World Bank (The World Bank n.d.a). The study is a result of harsh criticism to the project from neighboring Uzbekistan, that raised concerns, among other things, over a decrease in the downstream water flow the country needs for its irrigated agriculture.

Paradoxically, even though Rogun used to be a Soviet project, its significance increased when the Soviet Union ceased to exist. With independence - and with the vanishing of the centralized Soviet management system responsible for the allocation of resources to the Soviet republics - energy-poor Tajikistan had to start paying for the imports of gas, oil and coal necessary to fulfill its energy needs. However, the country's failure to pay for outstanding debts, combined with a tense relationship with Uzbekistan (its sole supplier of natural gas), resulted in recurrent cuts in energy supplies and in frequent energy crises. Currently, around 70 per cent of the Tajik population experience extensive electricity shortages in winter, which, alongside their social costs, cause an economic loss estimated at over US\$ 200 million per year (The World Bank 2012, i). Under such circumstances, the potential impact of a hydroelectric power plant of the size of Rogun is remarkable. Namely, as Tajikistan's electricity production from hydroelectric sources accounts for around 97 per cent of the total (The World Bank, n.d.b), the country's total installed capacity of 4,000 MW (European Bank for Reconstruction and Development, n.d.) would almost double with the additional 3,600 MW that the Rogun dam could generate, allowing Tajikistan not only to become energy secure ${ }^{5}$ but also to sell electricity to Afghanistan and Pakistan.

Even though it is probably too optimistic to predict that "with Rogun, Tajikistan will live like Kuwait," as declared in 2009 by a representative of Barki Tojik, the energy holding company of 
Tajikistan (Marat 2010), ideally many of the country's energy problems could potentially be resolved by the dam. This is even more relevant in light of the two exceptionally cold winters that hit Central Asia in 2007-2008 and 2008-2009, which engendered a major energy crisis in Tajikistan and in Kyrgyzstan, further aggravated by the Kazak and Uzbek withdrawal from the Central Asia Power System (The World Bank 2012, 56). However, it is worth noting that about $40 \%$ of the electricity produced in Tajikistan is used to power TalCo, the large state-owned aluminum plant located close to the border with Uzbekistan, which has priority over domestic consumers (The World Bank 2013a) and whose profits are transferred to an offshore company headquartered in the British Virgin Islands and linked to the GoT (IMF 2009, 21). There is thus the possibility that the Tajik government will prefer to export surplus electricity over satisfying domestic demand, as is often the case in the opaque Central Asian regimes where the ruling elites are in a position to make arbitrary decisions concerning the distribution of resources (Isaacs 2011).

Yet, it is on the political level that Rogun could have an even stronger impact. Tajikistan - the least prepared of the Central Asian countries to undergo policies of national consolidation (Gleason 1997, 100) - was ravaged by a harsh civil war (1992-97) that enfeebled the authority of the national government and accentuated regional and clan divisions (Akiner 2001). As soon as the war ended, Tajik President Emomali Rahmon started consolidating Tajik statehood and instilling a new Tajik national consciousness (Blakkisrud and Nozimova 2010), using symbols and creating ideologies. Symbols play an important role in Tajik politics, and as Roy observed, their use is first visible from the basic features of an independent state such as the design of its flag, which adopts the Iranian national colors in reverse and presents large amounts of green, the color of Islam (Roy 2000, 162). According to Erica Marat, Rahmon's ideological production after the end of the civil war was aimed at increasing his presidential power and alienating the Islamic opposition (Marat 2008). In this process, three elements appear to be central: the cult of Ismail Somoni, the celebrated Samanid ruler that became a symbol of the independence and strength of the Tajik state (Blakkisrud and Nozimova 2010); the revival of Zoroastrianism; and the Aryan myth (Laruelle 2007).

In the same way, it is argued, the symbolic value that stems from the Rogun dam has become in recent years the centerpiece of an ideological production propagated by the government to legitimize itself, gain consensus and assert its regional power. The unifying effect of such an iconic project can contribute to the creation of a common national identity, while helping to keep President Rahmon and his close network from the Kulob region in power. If Rogun is seen as a symbol of patriotism and 
success, it is understandable why the GoT wants it to be the tallest dam in the world. Having recently inaugurated the world's tallest flagpole and Central Asia's largest library (Parshin 2012), the GoT seems to pay particular attention to world and regional records. While the project envisages a final height of 335-meter, alternatives for a lower dam were proposed over the years (Eschanov 2011, 1582). The German engineering firm Lahmeyer, which was awarded a contract to carry out a first feasibility study of Rogun (Interfax 2005), recommended 285-meter as the ideal height of the dam (Associated Press 2006). Without these additional 50-meter, Rogun would still be a very tall dam, but not the tallest in the world. Also, a smaller project would be less controversial in downstream Uzbekistan and Turkmenistan, since it would have a less significant impact on the water flow of the Amu Darya (Wegerich et al. 2007). Nevertheless, President Rahmon's insistence on the taller version of the project was such that it led to the cancelation of the deal signed with RusAl (Eurasianet.org 2007). This insistence on having the tallest dam in the world is noteworthy, particularly if Rogun is analyzed through the lens of its symbolic significance. If, indeed, the GoT wants to persuade its citizens that the dam is a symbol of national pride and success, the power of suggestion that derives from a structure that stands taller than any other probably helps legitimize this message among those that receive it.

\section{The internal Rogun discourse}

The construction of the Rogun ideology gained momentum after the energy crisis of 2007-2008, which left many people without electricity and heating in many areas of the country, including the capital, Dushanbe (BBC Monitoring 2008a). At a moment in which the Tajik citizens were feeling particularly vulnerable to electricity shortages, convincing them of the many benefits of the Rogun dam became a priority for Rahmon. Fifty years after the construction of the Toktogul dam in the Kyrgyz SSR (Soviet Socialist Republic), which embodied the classical Soviet slogans on human's mastery over nature (in line with Lenin's insight “Communism is Soviet power plus the electrification of the whole country") and on the forceful domination of rivers (Feaux de la Croix 2011), yet another Soviet hydraulic project is being emotionally charged by a ruling elite. As Molle, Mollinga and Wester (2009) noted, the creation of certain meta-discourses and meta-justifications - which usually tend to stress matters such as the achievement of national goals and priorities or the absence of real alternatives - are among the classical means of furthering large-scale projects at the internal level. In the case of the 
Rogun dam, the discourse constructed by the Tajik political elite mainly presents the project as a source of pride and wellbeing and as a vital achievement in the country's development path.

Tajik state-owned media, such as the Khovar and Avesta news agencies and the Tajik TV and Radio, have worked together in both ensuring visibility to the project and in channeling official statements that report the government's vision for Rogun. For instance, the internet portal of the Avesta news agency features Rogun at the top of the list of topics addressed on the website ${ }^{6}$ (placing it before the "Government", "Security" and "Business" sections), while the Khovar news agency duly reports Rahmon's speeches on Rogun and mirrors the government's position on the matter. Indeed, the Tajik president has been by far the most vocal advocate for the dam, often using official occasions and ceremonies to glorify the importance of its construction. Already in 2006, during his New Year's speech, Rahmon (2006a) saluted the resumption of the dam's construction as a "joyful and memorable event," and later, during the celebrations for the Nowruz (the Persian New Year), he (Rahmon 2006b) underlined how the Rogun dam could ensure energy security and help "our beloved Tajikistan take its rightful place among the developed countries of the world."

Rahmon's messages became more frequent in 2008, taking the form of appeals to Tajik citizens. The country had just experienced a serious energy crisis, and after the cancelation of the RusAl deal, the government needed full internal support for the project. In an address to the Parliament, Rahmon used Islam as a tool for legitimation ${ }^{7}$, noting how water is a God-given gift that brings life and, in the case of hydroelectricity, precious energy that should not be wasted. He thus launched an appeal to "decent citizens that loved their homeland" to take an active part in the construction of the Rogun dam, which he branded as "a matter of life or death" that could ensure energy independence for Tajikistan (Rahmon 2008a). The appeal was disseminated on all the country's TV and radio channels (BBC Monitoring 2008b), and the same happened in 2010, when Khovar - along with the Tajik state TV and Radio , which broadcasted it in its entirety - reported the yearly Presidential address to the people of Tajikistan, which on this occasion was almost entirely centered on Rogun. In his message, Rahmon provided a comprehensive synthesis of the Rogun rhetoric:

Rogun is our national idea. [...] I shall reiterate to all citizens of this sovereign state, regardless of nationality, language and religion, that Rogun is a real battleground for honour and dignity, is a popular arena of selfless work for a better future and prosperity of sovereign Tajikistan! [...] I appeal to the children of Tajikistan, living and working in other countries, and always thinking about the welfare of their ancestral land and the prosperity of their houses: you can actively participate in this nation-wide 
initiative and contribute to the construction of Rogun, a source of light and heat in your homes! [...] Rogun is a symbol of the accomplishment and prosperity of the present and future Tajikistan, of an unprecedented development of industry and agriculture, and most importantly, a daily symbol of warmth and light for every citizen of our country! [...] Rogun is a source of national pride for every citizen of Tajikistan and a symbol of pride for our present and future life! Rogun is a symbol of the life of our nation, a symbol of life and death of the Tajik state! (Rahmon 2010a)

All the key elements of the Rogun discourse can be identified in this address: the dam is portrayed as a symbol of national pride and honor, of progress and prosperity, and once again, as a matter of life and death for Tajikistan. The appeal to the "children of Tajikistan" living abroad recalls the unifying effect of the dam, which appears relevant considering that the drawing of the Soviet borders left $60 \%$ of the Tajik population outside their home country (Bergne 2007, 100) and that the amount of remittances sent home by Tajik migrants is estimated to account for half of the GDP (ILO 2010).

This last aspect is even more significant when connected with the sale of Rogun shares to Tajik citizens, a consequence of the need to find financial resources to realize the project. Indeed, Rahmon has extensively used certain aspects of the Rogun discourse - namely the representation of the dam as an existential and vital facility - to convince his citizens to buy shares of the "Open Joint Stock Company Rogun" (Ministry of Finance of Tajikistan 2009). An initial public offering (IPO) was launched among festivities and celebrations on 6 January 2010 (Rasul-zade 2010), a day which was also declared the "Day of Solidarity for the Construction of Rogun" (Eurasianet.org 2010), and that was marked by the birth of a baby named by his family Roghunshoh, King Rogun, in honor of the power station (Ria Novosti 2010). During the IPO, Tajik citizens were forced to sacrifice part of their salaries to purchase shares of Rogun and university students had to show their shares before sitting for exams (BBC Monitoring 2010a), while the main streets of Dushanbe had been adorned with banners and posters advertising the dam (see Figure 1). In addition, following a precise request from Rahmon (BBC Monitoring 2009b) the Tajik state TV devoted substantial amounts of prime time broadcast to updates on the progress of the share sale. Only Tajik citizens and legal entities were allowed to buy the shares in order to preserve the national character of the dam. As Rahmon pointed out to TTFC, "there are foreign countries which are now ready to buy 70 per cent of them but I did not give them [the shares] and I am not going to. This is our national wealth" (BBC Monitoring 2009a). To further encourage the sale, the Tajik Assembly even adopted an exceptional one-off law that conceded amnesty to all who bought shares of the "great and crucial" Rogun dam (BBC Monitoring 2010c). One 
year later, some two million shares of Rogun had been sold, earning the Stock Company Rogun US\$ 170 million (Ergasheva 2011), corresponding to less than $10 \%$ of the total amount required to build the $\mathrm{dam}^{8}$.

This notwithstanding, the Tajik government has continued to disseminate its Rogun discourse with frequent reports on TTFC, praising the progress made in realizing the dam. Yet, the parallel conflict with Uzbekistan (which resulted in the launch of the above mentioned feasibility study financed by the World Bank) led to a change in the Tajik framing of the Rogun dam, with an increasing emphasis placed on Tajikistan's sovereignty over its natural resources. As Rahmon (BBC Monitoring 2011a) observed in his annual state-of-the-nation address, water is part of Tajikistan's natural wealth, "it is our national property, and we should fruitfully use it." The next section analyses this added dimension of the Rogun discourse, connecting it with the rivalry between Tajikistan and Uzbekistan and the Tajik portrayal of the dam as symbol of internal cohesion that epitomizes the nation's right to selfdetermination.

\section{Internationalizing the Rogun discourse}

The Uzbek opposition was successful in making the Rogun dam an internationally controversial matter. However, this has also had the unintended consequence of further convincing the Tajik government that the dam can be held up as a symbol of self-determination and success, one that can bond the people of Tajikistan around a national idea and against a common antagonist. Tajiks and Uzbeks share a common culture and traditions, and being the two main contemporary sedentary civilizations of Central Asia, they have also developed a fierce rivalry, one that was further exacerbated after the collapse of the Soviet Union due to the assignment of the cities of Samarkand and Bukhara to Uzbekistan. As Paul Bergne's (2007) historical analysis exhaustively illustrated, the birth of Tajikistan ${ }^{9}$ in the 1920s caused a profound shift in the way the Tajiks saw themselves, creating a Tajik national identity where there previously was none. "The founding of Tajikistan was not the result of Tajik nationalism but the hour of its birth" (Lutz Rzehak quoted in Bergne 2007, 103), and this new national identity almost immediately clashed with the Uzbek one. And indeed, the governments' claims about the existence of an ongoing Uzbek plot to weaken Tajikistan and its integrity as a nation gave rise to a developing Tajik nationalism (Heathershaw and Herzig 2013). This is also mirrored in the discursive 
constructions of the Rogun dam in which, unsurprisingly, the emphasis is placed on the nation as absolute sovereign and exclusive owner of its resources and territory.

The international dimension of the Rogun discourse is significant, since the projection of an international image is relevant to the nation and to the legitimation of an internal discourse (LeMarquand 1977; Frey 1993). Successfully persuading the international community that Rogun is a cooperative project that represents a key step in the country's development path can help the Tajik government gain consent to, and possibly financial support for, its realization. A foreign policy issue assumes relevance as a national, if not nationalistic, assertion of power against a rival and an enemy of the nation, in a matter related with national pride rather than with the water of the Amu Darya river itself.

The Tajik government has consequently used the national media to contest and discredit the Uzbek views on the Rogun dam, dubbing them as unreasonable and biased. Illustrative, in this regard, is a 2010 epistolary dispute between the Tajik Prime Minister, Akil Akilov, and his Uzbek counterpart, Shavkat Mirziyoyev, with letters being simultaneously published in the Tajik and Uzbek state-owned news agencies, thus informing citizens of both countries about the quarrel. When one of Akilov's missives (Akilov 2010) discarded the Uzbek view as unreasonable and stressed how the Rogun dam is based on the "vital necessity of normal electricity provision for population and national economy," the Tajik state-owned press noted that Uzbek criticisms have no other effect than uniting the people of Tajikistan in the idea of building this crucial facility, stimulating the sale of Rogun shares to Tajik patriots (BBC Monitoring 2010b).

Furthermore, the need to justify the construction of Rogun at the international level made the dam one of the cornerstones of Tajikistan's foreign policy. Of particular note is the effort carried out by the Tajik government to construct and project abroad the specific image of Tajikistan as a "water-country". Since 2005, the Tajik government has targeted international forums like the United Nations General Assembly (UNGA), the European Union and the Organization for Security and Cooperation in Europe (OSCE) Ministerial Council meetings, to execute a communication strategy aimed at portraying itself as a responsible water user and as a global leader in encouraging cooperation in the field of water. Keeping in mind that the desiccation of the Aral Sea - probably the worst manmade environmental disaster of the $20^{\text {th }}$ century - was caused by the series of dams and river diversion projects realized by the Soviet Union during its hydraulic mission, this strategy can be interpreted as an attempt to change 
the perception of Central Asia as an environmentally degraded region by bestowing on Tajikistan the label of "environmentally responsible".

In 2005, the then Tajik Foreign Minister Talbak Nazarov (2005) raised at the United Nations General Assembly (UNGA) the issue of Tajikistan and of its unexploited hydroelectric potential: "water resources possessed by Tajikistan provide us with considerable potential advantages in terms of the Millennium Development Goals (MDGs) implementation, since they represent a huge hydro potential that, unfortunately, is currently used by less than 5 per cent." The connection between Rogun and the achievement of the MDGs, which implies the representation of the dam as a fundamental element to attain national goals and priorities, became the central message delivered by Tajikistan at the UN during subsequent years (Aslov 2007; Rahmon 2008b, 2009a, 2009b). Tajikistan is presented as a benevolent country, one that "has all the rights to use its natural resources, including hydro-power, for the benefit of its people," and that sincerely advocates for mutually beneficial regional cooperation (Zarifi 2012). To further strengthen this cooperative image, the Tajik government has launched several global initiatives, including the proclamation of 2005-2015 as the "International Decade for Action Water for Life" and 2013 as the "International Year of Water Cooperation" (Rahmon 2010b).

Besides making a pitch for Rogun at some of the most important international organizations, the Tajik government supplemented its Rogun internationalization process by holding numerous UNbacked water conferences and seminars in its capital Dushanbe. During these events (such as the "High-level International Conference on Water Cooperation" that was held in Dushanbe in August 2013), the Tajik government presents its views on water management and tries to legitimize its right to develop its hydroelectric potential.

Hence, the international Rogun campaign comes back to Tajikistan, and its results are, unsurprisingly, well-advertised by the government. The most significant example is perhaps that of Struan Stevenson, a Member of the European Parliament (MEP) that in 2010 was appointed by the Kazakh Presidency of the OSCE as Personal Representative of the Chairman in Office responsible for the ecology and environment of Central Asia, and who has been an active supporter of the Rogun dam around European Institutions and international organisations. In the description of his first meeting with the Tajik president, Stevenson provides a powerful illustration of the high priority that Rahmon gives to the Rogun dam: 
The president began to thank me for my 'excellent' newspaper article about Rogun. He explained the importance of the project for Tajikistan and said that it was incomprehensible to him why Uzbekistan's president was so opposed to it. [...] President Rahmon suddenly lent forward and grabbed me tightly by the wrist. His face was only a few inches from mine. 'As you know I am coming to Strasbourg next week for meetings with the President of the European Parliament and for a debate with members of the Foreign Affairs Committee. I hope that I can meet you there, and I hope that you will repeat your support for our Rogun hydro project.' (Stevenson, 2012: 169-170)

Stevenson's stance in favor of the Rogun dam - expressed also in his OSCE report (Stevenson 2011) - is regularly reported by the Tajik media. The words of the MEP are used to add credibility and back the Rogun discourse held by the Tajik government at the internal level. This is significant, as it marks the intimate correlation between the two dimensions of the discourse, both internal and international, which reciprocally create and sustain the elite discourse and its representation of the Rogun dam as a national symbol that epitomizes Tajikistan and its realisation as a nation.

\section{Conclusions}

In their seminal book, Eric Hobsbawm and John Ranger (1983) illustrated how traditions, nationalism and symbolism are often invented and constructed by ruling groups to legitimize their power. This seems to fit also the case illustrated above, and although the Rogun dam is far from completion, the discourse revolving around the necessity of its realization has already been well constructed by President Rahmon. In a strategy aimed at legitimizing its own hold on power, the Tajik government portrayed the dam as a central element in the country's nation-building process, one that

symbolizes patriotism and a national identity. In line with this perspective, the construction of Rogun has thus been framed as a matter of national pride, a fundamental leap forward in national development, an existential achievement for the survival of the country, and ultimately, as a matter of life and death.

Even though Rahmon often declares that "achieving energy independence is the primary goal of Tajikistan's domestic policy, which will be achieved despite anything" (Interfax 2011), it seems that the construction of Rogun represents something that goes beyond the attainment of energy security. Resembling other similar infrastructures that became the end in themselves, instead of the means to an end (Molle et al. 2009), Rogun epitomizes Rahmon's ambitions of building a national identity and asserting the interest of a sovereign country through a mega-structure. Its symbolic power is used to 
construct not only a dam, but also, to say it as Bourdieu would, to construct a certain reality and establish a social order (Bourdieu and Thompson 1991).

Whether by making a pitch for the dam at the UNGA, or by adding a national solidarity day for the construction of Rogun to the calendar, the efforts to create a Rogun ideology have been remarkable and heterogeneous. Overall, there seem to be two main Rogun meta-discourses, one for the domestic and one for the foreign dimension, both aimed at generating misrecognition and gaining consent: the main prerequisites to successfully impose an ideology and a worldview. The former presents the dam as a panacea, as a symbol of national pride and honor, of progress and prosperity, as a national idea that should permeate all Tajiks. The latter focuses on presenting Tajikistan to the international community as a responsible water user that should be allowed - and possibly, financially supported - to exercise its right of building a dam that will be operated for the mutual benefit of all the countries in the region. Emblematically, at the most recent World Water Forum (held in France in 2012) the GoT disseminated

brochures and pens uttering the message "Tajikistan is a water country," thus ideally concluding the process aimed at indissolubly binding the idea of Tajikistan with that of water, and at projecting this specific image of the country internationally. It is hard to say whether Rogun will ever be built or if the project will keep up with the government's high expectations. Nevertheless, the symbolic meaning that has been attached to the dam is such that it appears difficult to imagine the Tajik government giving up on the project any time soon. It would imply that Tajikistan, at least in the words of Rahmon, has also given up on its national idea.

\section{References}

Akilov, Akil. 2010. Ofitsialnyy otvet pravitelstva Respubliki Tadzhikistan na pismo Premyer-Ministra Uzbekistana. Dushanbe.

Akiner, Shirin. 2001. Tajikistan: Disintegration or reconciliation? Central Asian and Caucasian prospects. London: Royal Institute of International Affairs.

Anderson, Benedict R. O'G. 2006. Imagined communities. 3rd ed. London, New York: Verso.

Aslov, Sirodjidin. 2007. Statement by the Permanent Representative of the Republic of Tajikistan to the United Nations H.E. Mr.Sirodjidin Aslov at the 62nd Session of the UN General Assembly. New York.

Associated Press. 2006. "Tajikistan, Russian investor seek World Bank expertise to solve dispute over power project.” April 19. 
BBC Monitoring Central Asia Unit. 2008a. "Paper says Tajikistan in grip of severe energy crisis, frosts." Asia-Plus, February 21.

- 2008b. "It is realistic to launch power plant's first unit in four years - Tajik leader." ITARTASS news agency, May 31.

_. 2009a. "Tajik leader urges people to buy new power plant's shares." Tajik Television First Channel, November 30.

_. 2009b. "Tajik leader calls on media to give objective coverage of country's goals." Khovar News Agency, December 9.

_. 2010a. "Tajik students say barred from exams for not buying power plant shares." Interfax News Agency, January 12.

—. 2010b. "Website says Uzbek premier's letter has united Tajik people." Khovar News Agency, February 6.

_.2010c. "Tajik leader signs law amnestying those who legalize funds for power plant." Tajik president's website, February 24.

_. 2011a. "Tajikistan to ensure energy self-sufficiency in next three years - president." Tajik Television First Channel, April 20.

_. 2011b. "Tajik president inaugurates "world's tallest" flagpole." Tajik Television First Channel, August 30.

Bergne, Paul. 2007. The birth of Tajikistan: National identity and the origins of the Republic. London:

I.B. Tauris.

Blakkisrud, Helge, and Shahnoza Nozimova. 2010. "History writing and nation building in postindependence Tajikistan.” Nationalities Papers 38 (2): 173-89. doi: 10.1080/00905990903517835.

Bourdieu, Pierre, and Jean C. Passeron. 1977. Reproduction in education, society and culture. Sage studies in social and educational change v. 5. London, Beverly Hills: Sage Publications.

Bourdieu, Pierre, and John B. Thompson. 1991. Language and symbolic power. Cambridge, Mass: Harvard University Press.

Brubaker, Rogers. 1996. Nationalism reframed: Nationhood and the national question in the New Europe. Cambridge [England], New York: Cambridge University Press.

Cloke, Paul J., Ian Cook, Philip Crang, Mark Goodwin, and Painter, Joe, Philo, Chris. 2004. Practising human geography. London, Thousand Oaks, Calif: SAGE.

Cummings, Sally N. 2002. Power and change in Central Asia. Politics in Asia series. London, New York: Routledge.

2010. Symbolism and power in Central Asia: Politics of the spectacular. London, New York: Routledge. 
. 2012. Understanding Central Asia: Politics and contested transformations. New York: Routledge.

D’Souza, Rohan. 2008. "Framing India's Hydraulic Crisis: The Politics of the Modern Large Dam.” Monthly Review 60 (3).

Deutsch, Karl W., and William J. Foltz. 1963. Nation-building. [The Atherton Press political science series]. New York: Atherton Press.

Dobbins, James. 2003. American's role in nation-building: From Germany to Iraq. Santa Monica: RAND.

Dorcey, Anthony H. J. 1997. Large dams: Learning from the past looking at the future : workshop proceedings, Gland, Switzerland, April 11-12, 1997. Washington, D.C: World Bank.

Dubnov, Arkady. 2009. "My vozmem Samarkand i Bukharu." Vremya Novostei, December 10. Accessed November 08, 2012. http://www.vremya.ru/2009/228/5/243519.html.

Ergasheva, Zarina. 2011. "Roghun's money gives first dividends.” Asia-Plus, January 24. Accessed October 11, 2012. http://www.news.tj/en/news/roghun-s-money-gives-first-dividends.

Eurasianet.org. 2007. “Does Dushanbe Want to Distance Itself From Russia?”, September 6. Accessed October 10, 2012. http://www.eurasianet.org/departments/insight/articles/eav090707aa.shtml.

Féaux de la Croix, Jeanne. 2011. "Moving metaphors we live by: water and flow in the social sciences and around hydroelectric dams in Kyrgyzstan." Central Asian Survey 30 (3-4): 487-502. doi: 10.1080/02634937.2011.614097.

Fradchuk, Artyom. 2010. "Tajikistan's Energy Dilemma." Institute for War and Peace Reporting, February 15. Accessed March 12, 2012. http://iwpr.net/report-news/tajikistans-energy-dilemma.

Frey, Frederick W. 1993. "The Political Context of Conflict and Cooperation Over International River Basins.” Water International 18 (1): 54-68. doi: 10.1080/02508069308686151.

Giglioli, Ilaria, and Erik Swyngedouw. 2008. "Let's Drink to the Great Thirst! Water and the Politics of Fractured Techno-natures in Sicily." International Journal of Urban and Regional Research 32 (2): 392-414. doi: 10.1111/j.1468-2427.2008.00789.x.

Gleason, Gregory. 1997. The Central Asian states: Discovering independence. Westview series on the post-Soviet republics. Boulder, Colo: Westview Press.

Heathershaw, John, and Edmund Herzig. 2013. The transformation of Tajikistan: The sources of statehood. ThirdWorlds. London: Routledge.

Hobsbawm, Eric J. 1992. Nations and nationalism since 1780: Programme, myth, reality. 2. ed. Cambridge: Cambridge Univ. Press.

Hobsbawm, Eric J., and Terence Ranger, eds. 1983. The invention of tradition. Cambridge: Cambridge University Press. 
Interfax News Agency. 2004. "RUSAL to help build aluminium smelter in Tajikistan." October 21. . 2011. "Tajikistan will become energy-independent by 2014 thanks to Rogun HPP - Rahmon." April 26.

ICOLD (International Commission on Large Dams). n.d. "Register of Dams. Viewed." n.d. Accessed January 16, 2013. http://www.icold-cigb.net/GB/World_register/general_synthesis.asp?IDA=207.

IFES (International Foundation for Electoral Systems). 2010. Public opinion in Tajikistan 2010: Findings from an IFES survey. Dushanbe: IFES.

ILO (International Labour Organization). 2010. Migration and Development in TajikistanEmigration, Return and Diaspora. Moscow.

IMF (International Monetary Fund). 2009. IMF Country Report No. 09/174. Washington D.C. - 2010. IMF Country Report No. 10/203. Washington D.C.

Isaacs, Rico. 2011. Party system formation in Kazakhstan: Between formal and informal politics. Central Asian studies series 26. London, New York: Routledge.

Kaika, Maria. 2006. "Dams as Symbols of Modernization: The Urbanization of Nature Between Geographical Imagination and Materiality." Annals of the Association of American Geographers 96 (2): 276-301. doi: 10.1111/j.1467-8306.2006.00478.x.

Khovar News Agency. 2013. "Tajikistan excerpt from the speech of MEP Struan Stevenson at Cambridge University at the Central Asia Forum.” March 5. Accessed April 18, 2013. http://khovar.tj/eng/foreign-policy/3745-tajikistan-excerpt-from-the-speech-of-mep-struanstevenson-at-cambridge-university-at-the-central-asia-forum.html.

Kolstø, Pål. 2000. Political construction sites: Nation-building in Russia and the post-Soviet states. Boulder, Colo: Westview Press.

- 2006. "National symbols as signs of unity and division." Ethnic and Racial Studies 29 (4): 676-701. doi: 10.1080/01419870600665409.

Kolstø, Pål, and Helge Blakkisrud. 2004. Nation-building and common values in Russia. Lanham: Rowman \& Littlefield Publishers.

Kuzio, Taras. 2002. "History, memory and nation building in the post-Soviet colonial space." Nationalities Papers 30 (2): 241-64. doi: 10.1080/00905990220140649.

Laruelle, Marlene. 2007. "The Return of the Aryan Myth: Tajikistan in Search of a Secularized National Ideology.” Nationalities Papers 35 (1): 51-70. doi: 10.1080/00905990601124462.

LeMarquand, David G. 1977. International rivers: The politics of cooperation. Vancouver, B.C: Westwater Research Centre, University of British Columbia.

Marat, Erica. 2008. National ideology and state-building in Kyrgyzstan and Tajikistan. Silk road paper. Washington, D.C: Central Asia-Caucasus Institute \& Silk Road Studies Program. 
17

Matveeva, Anna. 2009. "Legitimising Central Asian Authoritarianism: Political Manipulation and Symbolic Power.” Europe-Asia Studies 61 (7): 1095-121. doi: 10.1080/09668130903068624.

McCool, Daniel. 2012. River republic: The fall and rise of America's rivers. New York: Columbia University Press.

McCully, Patrick. 2001. Silenced rivers: The ecology and politics of large dams. London, Atlantic Highlands, N.J., USA: Zed Books.

Mellon, James G. 2010. "Myth, Legitimacy and Nationalism in Central Asia." Ethnopolitics 9 (2): 137-50. doi: 10.1080/17449050902725660.

Ministry of Finance of Tajikistan. 2009. "Obsuzhdeniya: Ob aktsiyakh i Sertifikatakh aktsiy OAO «Rogunskaya GES ».” December 12. Accessed November 09, 2012. http://minfin.tj/index.php?newsid=139.

Mitchell, Timothy. 2002. Rule of experts: Egypt, techno-politics, modernity. Berkeley: University of California Press.

Molle, Francois, Peter P. Mollinga, and Philippus Wester. 2009. "Hydraulic bureaucracies: Flows of water, flows of power." Water Alternatives 2 (3): 328-49.

Murzakulova, Asel, and John Schoeberlein. 2009. "The Invention of Legitimacy: Struggles in Kyrgyzstan to Craft an Effective Nation-State Ideology.” Europe-Asia Studies 61 (7): 1229-48. doi: $10.1080 / 09668130903068756$.

Nazarov, Talbak. 2005. Statement by the Minister of Foreign Affairs of the Republic of Tajikistan Academician Talbak Nazarov at the 60th Session of the UN General Assembly. New York.

Olcott, Martha Brill. 2012. Tajikistan's difficult development path: Carnegie Endowment for International Peace.

Parshin, Konstantin. 2012. "Tajikistan: Dushanbe Building Boom Blocks Out Economic Concerns." Eurasianet.org, May 1. Accessed October 12, 2012. http://www.eurasianet.org/node/65340.

Polese, Abel. 2011. "Language and Identity in Ukraine: Was it Really Nation-Building?" Studies of Transition States and Societies 3 (3): 36-50.

Polese, Abel, and Anna Wylegala. 2008. "Odessa and Lvov or Odesa and Lviv: How Important is a Letter? Reflections on the "Other" in Two Ukrainian Cities." Nationalities Papers 36 (5): 787-814. doi: 10.1080/00905990802373488.

Rahmon Emomali. 2006a. "Pozdravleniye po sluchayu novogo 2006 goda." Tajik president's website, January 1. Accessed October 05, 2013. http://www.president.tj/ru/node/6118. 
_. 2006b. "Pozdravleniye po sluchayu prazdnovaniya prazdnika «Navruz»." Tajik president's website, March 21. Accessed October 05, 2013. http://www.president.tj/ru/node/1408.

- 2008a. "Poslanie Prezidenta Tadzhikistana Emomali Rakhmona Parlamentu strany." Tajik president's website, April 15. Accessed October 05, 2013. http://www.president.tj/ru/node/867.

- 2008b. Statement by the President of the Republic of Tajikistan H.E. Mr. Emomali Rahmon at the 63rd Session of the UN General Assembly. New York.

. 2009a. Statement by the President of the Republic of Tajikistan, H. E. Mr. Emomali Rahmon at the 5th World Water Forum. Istanbul.

- 2009b. Statement by the President of the Republic of Tajikistan H.E. Mr. Emomali Rahmon at the 64th Session of the UN General Assembly. New York.

- 2010a. "Obrashcheniye Prezidenta Respubliki Tadzhikistan k Narodu Tadzhikistana.” Khovar News Agency, January 5. Accessed November 03, 2012. http://khovar.tj/rus/archive/17084obraschenie-prezidenta-respubliki-tadzhikistan-k-narodu-tadzhikistana.html.

- 2010b. Statement by the President of the Republic of Tajikistan H.E. Mr. Emomali Rahmon at the 64th Session of the UN General Assembly. New York.

Rasul-zade, Tila. 2010. "V Tadzhikistane nachalas svobodnaya realizatsiya aktsiy Rogunskoy GES." Ferghana News, January 6. Accessed November 11, 2012.

http://www.fergananews.com/news.php?id=13754.

Reisner, Marc. 1993. Cadillac desert: The American West and its disappearing water. Rev. and updated ed., 15. [printing]. A Penguin book Environment Current events. New York, N.Y. [u.a.]: Penguin Books.

Ria Novosti. 2010. "Baby boy in Tajikistan named in honor of hydroelectric dam.” January 7.

Roche, Sophie, and Sophie Hohmann. 2011. "Wedding rituals and the struggle over national identities.” Central Asian Survey 30 (1): 113-28. doi: 10.1080/02634937.2011.554065.

Roy, Arundhati, and Aradhana Seth. 2002. Dam/age: A film with Arundhati Roy. Brooklym, NY: First Run/Icarus Films.

Roy, Olivier. 2000. The new Central Asia: The creation of nations. The library of international relations 15. London [u.a.]: Tauris.

Schmidt, Roland. 2007. "Feasibility study for completion of the Rogun scheme, Tajikistan." Hydropower \& Dams (3).

Seton-Watson, Hugh. 1977. Nations and states: An enquiry into the origins of nations and the politics of nationalism. Boulder, Colo: Westview Press.

Sharma, C.V.J. 1989. Modern Temples of India: Selected Speeches of Jawaharlar Nehru at Irrigation and Power Projects. Delhi: Central Board of Irrigation and Power. 
Smith, Anthony D. 1998. Nationalism and modernism: A critical survey of recent theories of nations and nationalism. London, New York: Routledge.

Stevenson, Struan. 2011. Central Asia - an environmental cauldron: OSCE. 2012. Stalin's legacy: The Soviet war on nature. Edinburgh: Birlinn.

Swyngedouw, Erik. 1999. "Modernity and Hybridity: Nature, Regeneracionismo, and the Production of the Spanish Waterscape, 1890-1930." Annals of the Association of American Geographers 89 (3): 443-65.

The World Bank. n.d.a "Assessment Studies for Proposed Rogun Hydropower Project in Tajikistan." n.d. Accessed December 05, 2013. http://web.worldbank.org/WBSITE/EXTERNAL/COUNTRIES/ECAEXT/0,,contentMDK:2274332 5 pagePK:146736 piPK:146830 theSitePK:258599,00.html.

. n.d.b "Electricity production from hydroelectric sources (\% of total)." n.d. Accessed January 14, 2013. http://data.worldbank.org/indicator/EG.ELC.HYRO.ZS.

—. 2012. Tajikistan's Winter Energy Crisis: Electricity Supply and Demand Alternatives. Washington: The World Bank.

2013. "Study shows TALCO's potential to save energy." January 28. Accessed February 15, 2013. http://www.worldbank.org/en/news/feature/2013/01/28/study-shows-talco-potential-saveenergy.

Trend News Agency. 2012. “Tajikistan suspends works on Rogun HHP.” August 3.

Waterbury, John. 1979. Hydropolitics of the Nile Valley. 1st ed. Contemporary issues in the Middle East. Syracuse, N.Y: Syracuse University Press.

Wegerich, Kai, Oliver Olsson, and Jochen Froebrich. 2007. "Reliving the past in a changed environment: Hydropower ambitions, opportunities and constraints in Tajikistan.” Energy Policy 35 (7): 3815-25. doi: 10.1016/j.enpol.2007.01.024.

Wittfogel, Karl A. 1957. Oriental despotism;: A comparative study of total power. New Haven: Yale University Press.

Worster, Donald. 1985. Rivers of empire: Water, aridity, and the growth of the American West. 1st ed. New York: Pantheon Books.

Yerofeyeva N. 2002. "Rogunskaya GES v Tadzhikistane budet dostroyena. No dlya etogo nuzhny inostrannyye investitsii." Rossiyskaya Gazeta, October 25.

Zarifi, Hamrokhon. 2012. Statement by His Excellency Hamrokhon Zarifi Minister of Foreign Affairs of the Republic of Tajikistan at the general debate of the 67th session of the UN General Assembly. New York. 
${ }^{1}$ The Vakhsh river is one of the main tributaries of the Amu Darya river, the largest river of Central Asia.

${ }^{2}$ The International Commission on Large Dams (ICOLD) defines a major dam as a dam with a height of 150-meter or more from the foundation, a reservoir storage capacity of at least 25 cubic kilometres and an electrical generation capacity of at least 1000 megawatt. There are more than 300 dams of this category worldwide (Dorcey 1997, 19).

${ }^{3}$ According to the International Foundation for Electoral Systems (IFES) 2010 survey, 94 percent of those interviewed indicated Tajik television as the most used source of information on what is happening in Tajikistan (IFES 2010, 45).

${ }^{4}$ However only four years later, in 1958, Nehru seemed to have changed his opinion on the matter, deploring the quest for big dams as a "disease of gigantism" (D'Souza 2008, 112).

${ }^{5}$ Due to the country's lack of energy, Tajikistan's population has electricity for two-three hours a day from October to May (Trend News Agency 2012).

${ }^{6}$ See http://www.avesta.tj/, top-left column. Accessed March 01, 2013.

${ }^{7}$ As pointed out by Cummings $(2012,110)$, while Sharia (the Islamic law) has no official status in the Central Asian countries and the five regional leaders have declared their states secular, they have nevertheless used Islam as a legitimation tool, integrating it (each one differently) in their state ideologies.

${ }^{8}$ Later in 2011, the GoT interrupted the sale of Rogun shares following criticism of the IPO by the International Monetary Fund (IMF 2010).

${ }^{9}$ Tajikistan did not exist as an ethnically defined political unit before the Bolshevik revolution. In 1924, the USSR created the Tajik Autonomous SSR (ASSR), that was part of the larger Uzbek SSR. In 1929, the Tajik ASSR achieved the status of union republic, becoming the Tajik SSR. 